\title{
Defining a realistic control for the chloroform fumigation-incubation method using microscopic counting and ${ }^{14} \mathrm{C}$-substrates
}

\author{
William R. Horwath1, Eldor A. Paul², David Harris², Jeannette Norton ${ }^{3}$, Leslie Jagger ${ }^{2,4}$, and \\ Kenneth A. Horton ${ }^{\dagger}$ \\ ${ }^{1}$ Department of Land, Air and Water Resources, University of California, Davis, Davis, CA 95616-8627, USA; \\ ${ }^{2}$ Crop and Soil Science Department, Michigan State University, East Lansing, MI 48824, USA, \\ e-mail: eapaul@msu.edu; ${ }^{3}$ Department of Plants, Soils and Biometeorology, Utah State University, \\ Logan UT 84322-4820, USA; ${ }^{4}$ Research Education for Undergraduate Program, National Science Foundation. \\ Received 12 February 1996, accepted 29 June 1996.
}

Horwath, W. R., Paul, E. A., Harris, D., Norton, J., Jagger, L. and Horton, K. A. 1996. Defining a realistic control for the chloroform fumigation-incubation method using microscopic counting and ${ }^{14} \mathrm{C}$-substrates. Can. J. Soil Sci. 76 : $459-467$. Chloroform fumigation-incubation (CFI) has made possible the extensive characterization of soil microbial biomass carbon (C) (MBC). Defining the non-microbial C mineralized in soils following fumigation remains the major limitation of CFI. The mineralization of non-microbial $\mathrm{C}$ during $\mathrm{CFI}$ was examined by adding ${ }^{14} \mathrm{C}$-maize to soil before incubation. The decomposition of the ${ }^{14} \mathrm{C}$-maize during a 10 -d incubation after fumigation was $22.5 \%$ that in non-fumigated control soils. Re-inoculation of the fumigated soil raised ${ }^{14} \mathrm{C}$-maize decomposition to $77 \%$ that of the unfumigated control. A method was developed which varies the proportion of mineralized $\mathrm{C}$ from the unfumigated soil $\left(U F_{\mathrm{C}}\right)$ that is subtracted in calculating CFI biomasss $\mathrm{C}$. The proportion subtracted $(P)$ varies according to a linear function of the ratio of $\mathrm{C}$ mineralized in the fumigated $\left(F_{\mathrm{C}}\right)$ and unfumigated samples $\left(F_{\mathrm{C}} / U F_{\mathrm{C}}\right)$ with two parameters $K_{1}$ and $\left.K_{2}\left(P=K_{1} F_{\mathrm{C}} / U F_{\mathrm{C}}\right)+K_{2}\right)$. These parameters were estimated by regression of CFI biomass C, calculated according to the equation $M B C=\left(F_{\mathrm{C}}-P U F_{\mathrm{C}}\right) / 0.41$, against that derived by direct microscopy in a series of California soils. Parameter values which gave the best estimate of microscopic biomass from the fumigation data were $K_{1}=$ 0.29 and $K_{2}=0.23\left(R^{2}=0.87\right)$. Substituting these parameter values, the equation can be simplified to $M B C=1.73 F_{\mathrm{C}}-0.56 U F_{\mathrm{C}}$. The equation was applied to other CFI data to determine its effect on the measurement of MBC. The use of this approach corrected data that were previously difficult to interpret and helped to reveal temporal trends and changes in MBC associated with soil depth.

Key words: Chloroform fumigation-incubation, soil microbial biomass, microscopically estimated biomass, carbon, control, ${ }^{14} \mathrm{C}$

Horwath, W. R., Paul, E. A., Harris, D., Norton, J., Jagger, L. et Horton, K. A. 1996. Définition d'une mesure témoin réaliste de l'efficacité de la méthode de fumigation au chloroforme-incubation utilisant la numération microbienne et des substrats marqués au ${ }^{14} \mathrm{C}$. Can. J. Soil Sci. 76: 459-467. La fumigation au chloroforme avec incubation (FCI) a rendu possible une large caractérisation du C d'origine microbienne (CBM). La mesure du carbone non microbien minéralisé dans le sol à la suite de la fumigation demeure toutefois le principal facteur limitant de la FCI. Nous avons examiné la minéralisation du C non microbien durant la fumigation en incorporant au sol, avant l'incubation, du maïs marqué au ${ }^{14} \mathrm{C}$. La décomposition du maïs marqué, durant une période d'incubation de 10 jours suivant la fumigation, s'établissait à $22,5 \%$ de celle observée dans les sols témoins non fumigés. Après réensemencement microbien du sol fumigé, le taux de décomposition du maïs marqué grimpait à $77 \%$ de celui du sol témoin. Nous avons mis au point une méthode qui fait varier la proportion de $\mathrm{C}$ minéralisé du sol non fumigé (UF $\mathrm{C}$ ) qu'on doit soustraire dans le calcul du C de la biomasse après traitement FCI. La proportion soustraite (Pr) varie en fonction linéaire du rapport entre le $\mathrm{C}$ minéralisé dans le sol fumigé et le $\mathrm{C}$ minéralisé dans le sol fumigé $\left(F_{\mathrm{C}} / U F_{\mathrm{C}}\right)$, utilisant les deux paramètres $K_{1}$ et $K_{2}$, soit: $\operatorname{Pr}=K_{1}\left(F_{C} U F_{C}\right)+K_{2}$. Ces paramètres étaient estimés par régression du Ce la biomasse microbienne après FCI, estimée selon l'équation $\mathrm{CBM}=\left(F_{C}-P r F_{C}\right) / 0,41$ sur le carbone obtenu par numération microbienne directe dans une série de sols californiens. Les valeurs paramétriques qui produisaient les meilleures estimations de la biomasse mesurée par numération microbienne à partir des données de l'expérience de fumigation étaient $K_{1}=0,29$ et $K_{2}=0,23\left(R^{2}+0,87\right)$. L'inclusion de ces valeurs dans l'équation 1 permet de la simplifier à $C B M=1,73 F_{C}-0,56 U F_{C}$. L'équation a été appliquée à d'autres données d'essais FCI pour déterminer son effet sur la quantification de CBM. On a ainsi pu corriger des données auparavant difficiles à interpréter et mettre au jour des tendances et des modifications dans le temps de CBM en fonction de la profondeur du sol.

Mots clés: Fumigation de chloroforme-incubation, biomasse microbienne du sol, biomasse estimée par numération microbienne, carbone, témoin, ${ }^{14} \mathrm{C}$

${ }^{\dagger}$ Deceased. 
Microbial biomass plays a major role in soil as both a nutrient source and a catalyst in nutrient transformations. The most common methods to measure soil microbial biomass are based on chloroform-fumigation (Smith and Paul 1990). The application of the CFI method is confounded by the difficulty in ascertaining the contribution of non-microbial $\mathrm{C}$ to the fumigation flush $\left(F_{C}\right)$ (Horwath and Paul 1994). In soils with relatively low microbial biomass but high respiration activity, the subtraction of the $\mathrm{CO}_{2}$ evolved from an unfumigated sample (uncorrected control) often leads to low or negative biomass estimates. Jenkinson et al. (1976), recognized this problem and suggested subtracting the $\mathrm{CO}_{2}$ mineralized during the 10 - to $20-\mathrm{d}$ incubation of non-fumigated soil $\left(U F_{\mathrm{C} 10-20}\right)$ from $F_{\mathrm{C}}$ to compensate for the mineralization of non-microbial $C$. Subtraction of $U F_{\mathrm{C} 10-20}$ decreases the proportion of low or negative biomass estimates in comparison to subtracting the $0-$ to $10-\mathrm{d}$ respiration $\left(U F_{\mathrm{C}}\right)$. However, it does not represent what happens during the initial $10 \mathrm{~d}$ and therefore does not constitute a true control.

The chloroform fumigation extraction (CFE) method has fewer problems with defining a control. It is more rapid, although requiring additional analytical procedures (i.e. C digests followed by titration, Kjeldahl procedures for organic $\mathrm{N}$, etc.) for the determination of $\mathrm{C}$ and $\mathrm{N}$ which can lead to inconsistent results as compared to CFI. These problems can be corrected by using better instrumentation such as liquid $\mathrm{C}$ and $\mathrm{N}$ analysers. Because of the problems with interpreting the CFI control, CFE is gaining wider usage. Studies with CFE have shown increases in the extraction of nonmicrobial carbon (Martens 1985; Badalucco et al. 1990; Couteaux et al. 1990; Martikainen and Palojärvi 1990). Also it is difficult to consolidate the $\mathrm{C}$ and $\mathrm{N}$ isotopes for mass spectrometry or scintillation counting (Horwath and Paul 1994). Other methods such as the measurement of ATP or substrate-induced respiration cannot be used for the measurement of tracers in the soil microbial biomass. Of the available methods, CFI is best suited for measurement of tracers in the soil microbial biomass.

The CFI method was originally calibrated against nine soils from two locations by microscopic biovolume determination and addition of microorganisms grown in vitro (Jenkinson 1976; Jenkinson et al. 1976). Microbial C was calculated using a $K_{\mathrm{c}}$ (correction factor) of 0.45 to 0.5 , i.e. the fraction of microbial $\mathrm{C}$ mineralized in $10 \mathrm{~d}$. Microscopy is a direct estimate of biovolume, however, biovolume to weight, $\mathrm{C}$, and $\mathrm{N}$ conversions have remained problematic (Paul and Clark 1996; Bottomley 1994). A $K_{\mathrm{C}}$ value of 0.41 was derived from the decomposition of 16 fungal and 12 bacterial species labeled with ${ }^{14} \mathrm{C}$ in four soils (Anderson and Domsch 1978). Voroney and Paul (1984), proposed a $K_{\mathrm{c}}$ of 0.41 without the subtraction of a control. This was obtained by fumigation of soils where a ${ }^{14} \mathrm{C}$ labeled microbial biomass had previously been developed by adding labeled glucose and incubation.

The control problem is the greatest when the $\mathrm{CO}_{2}$ mineralization from unfumigated soils $\left(U F_{\mathrm{C}}\right)$ approaches or is higher than that obtained from a fumigated sample $\left(F_{C}\right)$. The problem is small when the $F_{\mathrm{C}}$ to $U F_{\mathrm{C}}$ ratio is wide. We hypothesized that it should be possible to vary the proportion of the control $(P)$ to subtract from $F_{\mathrm{C}}$ as a function of the $F_{C} / U F_{C}$ ratio. To accomplish this, we modified the CFI biomass $\mathrm{C}$ calculation to subtract a variable proportion of the control. The proportion subtracted $(P)$ was set as a linear function of the $F_{C} / U F_{C}$ ratio and the parameters of the function were estimated by regression of fumigation data against microscopic biomass measurements for a series of soils. The ability of unfumigated and fumigated soils to decompose non-microbial $\mathrm{C}$ was measured with hot-water washed ${ }^{14} \mathrm{C}$ maize straw.

\section{MATERIALS AND METHODS}

\section{Determination of the Mineralization of Non- microbial C}

The soils examined represented a wide range of soil organic $\mathrm{C}$ and $\mathrm{N}$ contents and differences in vegetation, management, and soil type. Soils from California and Colorado were air dried prior to use (Table 1 ). The remaining soils were collected from the field and stored moist at $4^{\circ} \mathrm{C}$ until used. Soils were sieved through a 4-mm screen and gravimetric moisture content was determined after drying at $105^{\circ} \mathrm{C}$ for $24 \mathrm{~h}$. For the laboratory incubations, soils were adjusted to $55 \%$ of water-holding capacity. The air-dried soils were pre-incubated for $7 \mathrm{~d}$ after re-wetting. Uniformly labeled ${ }^{14} \mathrm{C}$ maize straw $\left(233 \mathrm{~Bq} \mathrm{mg}^{-1} \mathrm{C}\right)$, leached in hot water to remove easily decomposable material, was used to determine the proportion of non-microbial $\mathrm{C}$ mineralized to $\mathrm{CO}_{2}$ in fumigated and unfumigated soils.

The leached maize straw was used as a model for that part of the soil organic matter (SOM) which is not humified or stabilized as microbial by-products. This approach has also been used by Smith et al. (1995). The maize (2-3 g) was ground in a Wiley Mill to pass a 20-mesh screen, extracted in a glass beaker with $150 \mathrm{~mL}$ of hot water $\left(80^{\circ} \mathrm{C}\right)$, swirled, and vacuum filtered through a No. 1 Whatman filter for a total of three extractions. The extracted material was dried at $70^{\circ} \mathrm{C}$. Leached maize straw $(7 \mathrm{mg})$ was added to $15 \mathrm{~g}$ soil (dry weight). A set of soils was fumigated with ethanol-free chloroform (Jenkinson and Powlson 1976) for 18-24 h immediately after the addition of labeled maize straw. The chloroform was removed and the soils and controls were incubated at $25^{\circ} \mathrm{C}$ for $10 \mathrm{~d}$ (Horwath and Paul 1994). A separate set of fumigated soils containing the labeled maize received fresh soil ( $1 \%$ by weight) to determine the effects of an inoculum on the mineralization of non-microbial $\mathrm{C}$. Soil $\mathrm{C}$ and ${ }^{14} \mathrm{C}$ mineralization were determined in fumigated and non-fumigated soil by trapping $\mathrm{CO}_{2}$ in $1 \mathrm{~mL} 2.0 \mathrm{M}$ $\mathrm{NaOH}$. An aliquot $(0.1 \mathrm{~mL})$ from each alkali trap was mixed with $10 \mathrm{~mL}$ of scintillation fluid (Scintiverse II, Fisher Scientific) and the ${ }^{14} \mathrm{C}$ determined in a liquid scintillation spectrometer (Packard Instrument Co., Downers Grove, IL). The excess $\mathrm{NaOH}$ was titrated with $0.5 \mathrm{M} \mathrm{HCl}$ to a phenolpthalein endpoint after the addition of $\mathrm{BaCl}_{2}$ (Horwath and Paul 1994). The ${ }^{14} \mathrm{C}$ mineralized in fumigated soil was expressed relative to the amount mineralized in corresponding non-fumigated control incubations. 


\begin{tabular}{|c|c|c|c|c|c|c|}
\hline Location & Site & Soil Subgroup & $\begin{array}{l}\text { Depth } \\
(\mathrm{cm})\end{array}$ & $\begin{array}{l}\text { Vegetation } \\
\text { System }\end{array}$ & $\begin{array}{c}\mathrm{C} \\
\left(\mathrm{g} \mathrm{kg}^{-1}\right) \\
\end{array}$ & $\begin{array}{c}\mathrm{N} \\
\left(\mathrm{g} \mathrm{kg}^{-1}\right) \\
\end{array}$ \\
\hline \multirow[t]{5}{*}{ California } & Old growth reserve & Ultic Haploxeralf & $0-10$ & Mixed conifer & 70.0 & 2.7 \\
\hline & 1980 clear cut ${ }^{\mathbf{z}}$ & Ultic Haploxeralf & $0-10$ & Mixed conifer & 39.0 & 1.6 \\
\hline & & & $10-20$ & Mixed conifer & 28.0 & 1.2 \\
\hline & 1975 clear cut $^{2}$ & Ultic Haploxeralf & $0-10$ & Mixed conifer & 52.0 & 2.1 \\
\hline & Sierra Field Station & Mollic Haploxeralf & $0-4$ & Grassland & 26.4 & 2.2 \\
\hline Colorado & Central great plains ${ }^{\mathbf{y}}$ & Aridic Paleustoll & $0-25$ & Wheat/fallow & 21.0 & 1.8 \\
\hline \multirow[t]{7}{*}{ Michigan } & $\begin{array}{l}\text { Saginaw Valley bean } \\
\text { and beet farm }\end{array}$ & Aeric Haplaquept & $0-10$ & $\begin{array}{c}\text { Corn/bean/ } \\
\text { sugar beat/alfalfa }\end{array}$ & 15.8 & 1.7 \\
\hline & Kellogg Exp. Forestw & Typic Hapludalf & $0-10$ & Red pine & 11.0 & 1.3 \\
\hline & & Typic Hapludalf & $0-10$ & Black oak & 18.4 & 1.3 \\
\hline & Kellogg Biological & Typic Hapludalf & $0-10$ & Hybrid poplar/ & 11.0 & 1.0 \\
\hline & Station $^{w}$ & & $10-25$ & Agronomic plots & 10.1 & 0.9 \\
\hline & & & $25-60$ & & 3.7 & 0.3 \\
\hline & & & $60-100$ & & 2.7 & 0.3 \\
\hline
\end{tabular}

${ }^{\mathbf{z}}$ Blodgett Exp. Forest, University of California, Berkeley, CA., The California soils do not fit the Canadian soil taxonomy but are Luvisols

${ }^{y}$ Central Great Plains Exp. Station, Arkon, CO., Orthic Brown Chernozemic.

"Michigan State University, Saginaw, MI., Orthic Humic Gleysol.

wMichigan State University, Hickory Corners, MI., Orthic Gray Brown Luvisol.

\section{The Determination of the Partial Control Relationship}

Microscopic biomass estimates were compared to CFI biomass during long-term incubation of California forest soils to determine the fraction of control to subtract from fumigated samples. The soil was incubated in specimen containers $(140 \mathrm{~mL})$ with a $1-\mathrm{mm}$ hole drilled into the cap to facilitate oxygen diffusion. Soil moisture was maintained at $55 \%$ of water-holding capacity by addition of deionized water on a gravimetric basis. Microbial biomass was determined on days 0,80 , and 160 by CFI and microscopy.

The partial control relationship was validated on soils from a poplar plantation and a long-term agronomic study (Robertson et al. 1996) in Michigan (Table 1). Soils from the poplar site were sampled to a depth of $100 \mathrm{~cm}$ at intervals of $0-25 \mathrm{~cm}, 25-60 \mathrm{~cm}$, and $60-100 \mathrm{~cm}$, sieved through a 4-mm screen, and stored at $4^{\circ} \mathrm{C}$ until used (Horwath et al. 1994). The soils from the agronomic site were sampled from 0 to $10 \mathrm{~cm}$, sieved through a $4-\mathrm{mm}$ screen, and stored at $4^{\circ} \mathrm{C}$ until used.

Microbial $\mathrm{C}$ was estimated by the CFI method (Horwath and Paul 1994). Microscopic biomass estimates on subsamples of California soils (1 g ) (Norton et al. 1990) were made after dispersion by blending at high speed for $4 \mathrm{~min}$ in 50 $\mathrm{mL}$ of $50 \mathrm{mM}$ Tris buffer $\mathrm{pH} 7.5$ (Ramsay 1984). Soil smears were prepared and stained with fluorescein isothiocyanate (Babuik and Paul 1970). Bacteria were counted in three size classes and numbers converted to biovolume. To determine the biovolume of fungal hyphae, the soil suspension was stained with trypan blue (Ingham and Klein 1984). Soil dilutions were filtered onto $0.2 \mu \mathrm{m}$ cellulose triacetate membrane filters and air dried. Filters were clarified with mineral oil and observed at $500 \times$ magnification. The length and diameter of the fungal hyphae were measured using an eyepiece graticule. Each determination consisted of two soil samples, four replicate smears or filters and 10 fields per smear or filter. Bacterial biomass determination on other soils were made using acridine-orange-stained soil. Soil (10 g) was homogenized with $200 \mathrm{~mL}$ of $0.2 \mathrm{M}$ Tris (pH 8) in a Waring blender for $60 \mathrm{~s}$. Serial dilutions of $1 \mathrm{~mL}$ homogenate to $9 \mathrm{~mL}$ Tris buffer were done to obtain $0.1 \mathrm{mg}$ soil $\mathrm{mL}^{-1}$ for bacteria and $0.5 \mathrm{mg}$ soil mL $\mathrm{mL}^{-1}$ for fungi. The final dilutions were stained with $0.5 \mathrm{~mL}$ acridine orange $(0.1 \% \mathrm{wt} / \mathrm{vol}$ in water) for $10 \mathrm{~min}$ (Faegri et al. 1977). The dilutions were preserved by adding $0.1 \mathrm{~mL}$ formaldehyde. The dilution was drawn through a pre-wetted $(1 \mathrm{~mL} 0.1 \%$ Tween 80 in water) $0.2 \mu \mathrm{m}$ black Nucleopore membrane filter on a vacuum side arm flask. Graticule fields were counted randomly until at least 300 bacteria were counted using a fluorescence microscope. Fungal hyphal length was determined by the line intersect method (Hanssen et al. 1974). A mean volume of $0.12 \mu \mathrm{m}^{3}$ for bacteria (Bakken and Olsen 1983 ) and a $2.3-\mu \mathrm{m}$ diameter for fungi were used in the calculation of biovolume. Carbon content of bacteria and fungi

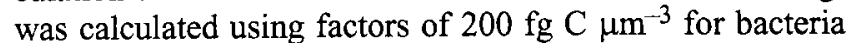
(Bloem at al. 1995) and $150 \mathrm{fg} \mathrm{C} \mu \mathrm{m}^{-3}$ for fungi (Paul and Clark 1996).

\section{RESULTS}

\section{Decomposition of ${ }^{14} \mathrm{C}$ Maize}

The $\mathrm{C}$ content of the California soils ranged from $26.4 \mathrm{~g}$ $\mathrm{kg}^{-1}$ in the annual grassland to $70.0 \mathrm{~g} \mathrm{~kg}^{-1}$ in an old growth forest (Table 1). Nitrogen varied similarly to give $\mathrm{C}: \mathrm{N}$ ratios in the mid 20's. The mineral horizon of Michigan soils contained 10 to $18 \mathrm{~g} \mathrm{C} \mathrm{kg}^{-1}$ with $\mathrm{C}: \mathrm{N}$ ratios of 8.5 to 14 . The subsurface soil $\mathrm{C}(>25 \mathrm{~cm}$ in depth) from Michigan soils ranged from 2.7 to $3.7 \mathrm{~g} \mathrm{~kg}^{-1}$ and had $\mathrm{C}: \mathrm{N}$ ratios between 9 
and 12 . The $\mathrm{C}$ and $\mathrm{N}$ contents of the Colorado dry land soil were intermediate between the Michigan and California soils. The $\mathrm{CO}_{2}$ evolved in a 10-d incubation represented $0.6 \%$ of total $\mathrm{C}$ in the California old growth and $10 \%$ of Michigan Red Pine soil (Table 2). The high activity of the red pine site was reflected in the narrow $\mathrm{C}: \mathrm{N}$ ratio of 8.5 (Table 1). Problems involved in using a control are exemplified by the fact that $U F_{\mathrm{C}}$ exceeded $F_{\mathrm{C}}$ in the three Michigan soils (Table 2).

Re-inoculating the $\mathrm{F}_{\mathrm{C}}$ sample resulted in a $10-33 \%$ increase in $\mathrm{CO}_{2}$ production over the non-inoculated $F_{\mathrm{C}}$ sample (Table 2). The Colorado dry land showed the lowest increase at $10 \%$, and the California old growth soil showed the highest effect at $33 \%$. The mineralization of ${ }^{14} \mathrm{C}$, leached maize was consistently greater in the reinoculated soils rel- ative to total $\mathrm{CO}_{2}$ mineralization. The non-inoculated $F_{\mathrm{C}}$ soils showed an average $22.5 \%$ degradation of the ${ }^{14} \mathrm{C}$ maize relative to $U F_{\mathrm{C}}$. The re-inoculated $F_{\mathrm{C}}$ mineralized an average of $77 \%$ of the ${ }^{14} \mathrm{C}$ maize relative to $U F_{\mathrm{C}}$. This indicated that organisms added in the inoculum can attack plant residues in fumigated soils and that decomposition in the fumigated soil is limited by lack of competent organisms.

\section{Subtraction of a Partial Control}

Both soil depth and incubation length reduced the rate of $\mathrm{CO}_{2}$ mineralization in the California forest soils (Table 3). The $\mathrm{CO}_{2}$ produced in the 10 to $20 \mathrm{~d}$ period represented $87-92 \%$ of that found in the 0 to $10 \mathrm{~d}$ incubation. Fumigation resulted in $\mathrm{CO}_{2}$ production that in some cases was similar to the control, in other cases it was four times

Table 2. Respiration of soil $\mathrm{C}$ and mineralization of the washed ${ }^{14} \mathrm{C}$-maize straw in noninoculated and inoculated fumigated soil. The mineralization of the ${ }^{14} \mathrm{C}$-maize is expressed as the amount respired in $F_{C}$ in relation to $U F_{C}$ Standard error of the mean shown in parentheses

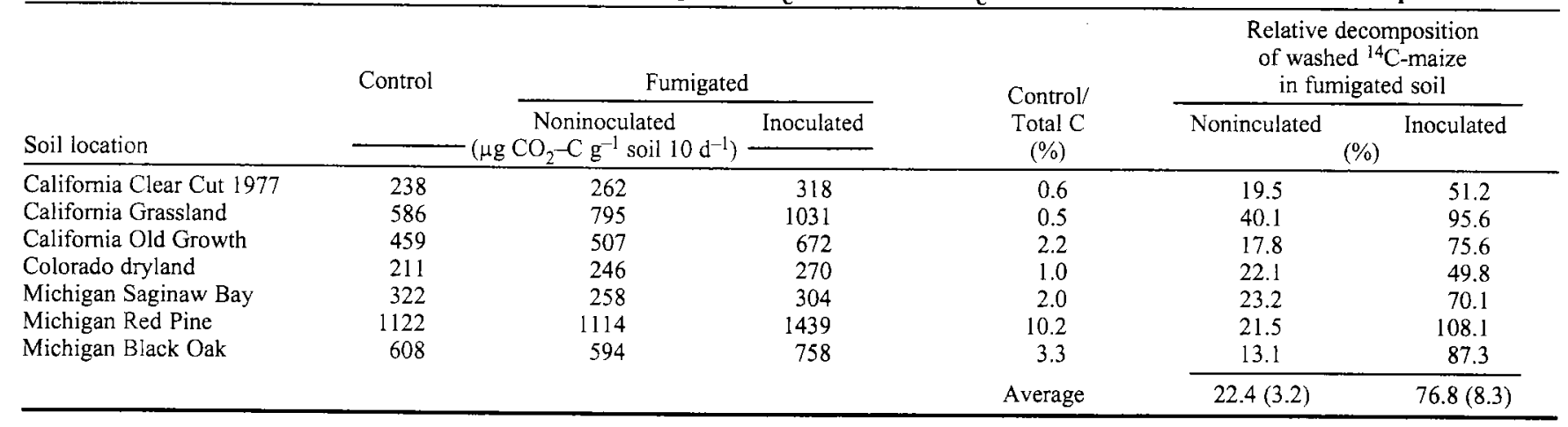

Table 3. Comparison of microscopic biomass and CFI methods using no control. $U F_{C} U F_{C 10-20}$, and Eq. 3. The ratio of $F_{C}\left(U F_{C}\right)$ and $P$ are also shown

\begin{tabular}{|c|c|c|c|c|c|c|c|c|c|c|c|}
\hline \multirow[b]{2}{*}{ Soil } & \multirow[b]{2}{*}{$\begin{array}{c}\text { Days } \\
\text { incubated }\end{array}$} & \multicolumn{3}{|c|}{$\begin{array}{c}\mathrm{CO}_{2} \text { evolved } \\
\left(\mu \mathrm{g} \mathrm{C} \mathrm{g}^{-1}\right) \\
\end{array}$} & \multirow{2}{*}{$\begin{array}{c}\text { Microscopic } \\
\text { biomass } \\
\left(\mu \mathrm{g} \mathrm{C} \mathrm{g}^{-1}\right)\end{array}$} & \multicolumn{3}{|c|}{$\begin{array}{l}\text { CFI biomass } \\
\left(\mu \mathrm{g} \mathrm{C}^{-1}\right)\end{array}$} & \multicolumn{3}{|c|}{$\begin{array}{l}\text { CFI microbial biomass } \\
\text { using partial control }(\mathrm{P}) \\
\left(\mu \mathrm{g} \mathrm{C} \mathrm{g}^{-1}\right)\end{array}$} \\
\hline & & $\begin{array}{r}U F_{C} \\
0-10 \mathrm{~d} \\
\end{array}$ & $\begin{array}{c}U F_{C} \\
10-20 \mathrm{~d} \\
\end{array}$ & $\begin{array}{c}F_{C} \\
0-10 \mathrm{~d} \\
\end{array}$ & & $F_{C} 0.41$ & $\begin{array}{c}\left(F_{C} U F_{C}\right) \\
{ }_{10.41} \\
\end{array}$ & $\begin{array}{c}\left(F C-U F_{C 10-20}\right) \\
/ 0.45\end{array}$ & $F_{C}\left(U F_{C}\right)$ & $P$ & $\begin{array}{c}\left(F_{C}-\left(U F_{C} \times P\right)\right) \\
/ 0.41 \\
\end{array}$ \\
\hline \multicolumn{12}{|c|}{ Old growth forest } \\
\hline H-layer & 0 & 1374 & 1200 & 1439 & 1537 & 3510 & 156 & 530 & 1.0 & 0.5 & 1691 \\
\hline $0-5$ & 0 & 401 & 357 & 393 & 564 & 959 & $(-20)$ & 80 & 1.0 & 0.5 & 447 \\
\hline $5-10$ & 0 & 265 & 245 & 265 & 393 & 646 & 0 & 44 & 1.0 & 0.5 & 305 \\
\hline H layer & 80 & 486 & 425 & 612 & 1021 & 1493 & 307 & 417 & 1.3 & 0.6 & 774 \\
\hline $0-5$ & 80 & 163 & 145 & 313 & 323 & 763 & 365 & 373 & 1.9 & 0.8 & 444 \\
\hline H layer & 160 & 165 & 144 & 575 & 1033 & 1402 & 1000 & 957 & 3.5 & 1.2 & 891 \\
\hline $0-5$ & 160 & 64 & 57 & 257 & 318 & 627 & 472 & 445 & 4.0 & 1.4 & 404 \\
\hline \multicolumn{12}{|c|}{1980 clear cut } \\
\hline $0-5$ & 0 & 222 & 198 & 408 & 587 & 995 & 454 & 467 & 1.8 & 0.8 & 573 \\
\hline $5-10$ & 0 & 173 & 155 & 290 & 640 & 707 & 285 & 300 & 1.7 & 0.7 & 399 \\
\hline $10-20$ & 0 & 88 & 72 & 138 & 349 & 337 & 122 & 147 & 1.6 & 0.7 & 187 \\
\hline $0-5$ & 80 & 91 & 81 & 318 & 327 & 776 & 554 & 527 & 3.5 & 1.2 & 493 \\
\hline $5-10$ & 80 & 74 & 66 & 259 & 255 & 632 & 451 & 429 & 3.5 & 1.2 & 401 \\
\hline $10-20$ & 80 & 19 & 16 & 125 & 193 & 305 & 259 & 242 & 6.6 & 2.1 & 203 \\
\hline $0-5$ & 160 & 36 & 32 & 225 & 271 & 549 & 461 & 429 & 6.3 & 2.0 & 365 \\
\hline $5-10$ & 160 & 31 & 27 & 109 & 262 & 266 & 190 & 182 & 3.5 & 1.2 & 169 \\
\hline $10-20$ & 160 & 4 & 3 & 92 & 172 & 224 & 215 & 198 & 23.0 & 6.9 & 155 \\
\hline \multicolumn{12}{|c|}{1975 clear cut } \\
\hline $0-5$ & 0 & 154 & 127 & 153 & 287 & 373 & $(-2)$ & 58 & 1.0 & 0.5 & 175 \\
\hline $5-10$ & 0 & 92 & 79 & 121 & 278 & 295 & 71 & 93 & 1.3 & 0.6 & 155 \\
\hline
\end{tabular}


greater. Calculation of the CFI biomass, without subtracting a control, resulted in high values compared with microscopically determined biomass $\mathrm{C}$. The use of the 10 to $20 \mathrm{~d}$ control resulted in a great range of biomass estimates with little relationship to microscopically determined biomass.

We hypothesized that the proportion $(P)$ of the 0 to $10 \mathrm{~d}$ control $\left(U F_{\mathrm{C}}\right)$ that should be subtracted from the fumigated flush $\left(F_{\mathrm{C}}\right)$ would vary as a function of the ratio $F_{\mathrm{C}} U U F_{\mathrm{C}}$ such that when $F_{\mathrm{C}} / U F_{\mathrm{C}}$ is large (small $U F_{\mathrm{C}}$ ) $P$ is large and when $F_{C} / U F_{\mathrm{C}}$ is small (large $\left.U F_{\mathrm{C}}\right) P$ is small. A linear function was used to determine the fraction of the control to subtract from the fumigated flush:

$$
P=K_{1}\left(\frac{F_{C}}{U F_{C}}\right)+K_{2}
$$

where $P$ is the fraction of $U F_{\mathrm{C}}$ to subtract from $F_{\mathrm{C}}$. Therefore, $\mathrm{MBC}$ equaled:

$$
M B C=\left(F_{C}-\left(P U F_{C}\right)\right) / 0.41
$$

Combining the two equations gives:

$$
M B C=\left[F_{C}-\left(U F_{C}\left(K_{1}\left(\frac{F_{C}}{U F_{C}}\right)+K_{2}\right)\right)\right] / 0.41
$$

which simplifies to:

$$
M B C=\left(F_{C}\left(1-K_{1}\right)-U F_{C} K_{2}\right) / 0.41
$$

The parameters $K_{1}$ and $K_{2}$ were estimated from the data for the California soils by regression using the model in Eq. 4 . The values of the parameters, $K_{1}=0.29$ and $K_{2}=0.23$, are those which provide the best prediction of the microscopically determined biomass $\mathrm{C}$ from $F_{\mathrm{C}}$ and $U F_{\mathrm{C}}$ using Eq. 4 $\left(R^{2}=0.87\right)$. Substituting these parameter values, Eq. 4 can be further simplified to:

$$
M B C=1.73 F_{C}-0.56 U F_{C}
$$

The constants in Eq. 5 can also be obtained directly by regression of the fumigation and microscopic data. The $F_{\mathrm{C}} / U F_{\mathrm{C}}$ ratio ranged from 1.0 to 23.0 . This resulted in values for $P$ (Eq. 1) that ranged from 0.5 to 6.9 (Table 3 ). We compared the relationship between MBC estimates obtained by Eq. 4 with values obtained by previous calculation methods. Figure 1a shows the relationship between microscopic biomass $\mathrm{C}$ and that calculated from Eq. 4 using the fitted values for $K_{1}$ and $K_{2}$ which gave a slope of 0.96 . Regression of CFI biomass $\mathrm{C}$ calculated without subtracting a control ( $\left.\mathrm{MBC}=F_{\mathrm{C}} / 0.41\right)$ against microscopic biomass $\mathrm{C}$ gave a similar $R^{2}(0.87)$ but overestimated microscopic biomass C by a factor of 2.1 (Fig. 1b). Subtracting a 10- to 20-d control $\left(M B C=\left(F_{\mathrm{C}}-U F_{\mathrm{C} 10-20}\right) / 0.45\right)$ resulted in values with a weak relationship to microscopic biomass $C$ (slope $=0.36$, $R^{2}=0.29$ ). Jenkinson et al. (1976) said that the CFI tech- nique would not work on acid forest soils. The soils in this study are neutral in $\mathrm{pH}$, but contain a large amount of decomposable organic material and a large range in biomass C.

\section{Validation of the Partial Control Model}

The partial control relationship determined on California soils was applied to several soils taken from three depths in a hybrid poplar plantation and from the surface $(0-15 \mathrm{~cm})$ of a long-term agronomic study in Michigan to test its utility in soil microbial biomass estimations. The microscopically determined bacterial biomass $\mathrm{C}$ in surface samples from poplars ranged from 30 to $39 \mu \mathrm{g} \mathrm{C} \mathrm{g}^{-1}$ soil and from 48 to $73 \mu \mathrm{g} \mathrm{C} \mathrm{g}^{-1}$ in the agronomic plots. The MBC estimates, using Eq. 4 with the parameter values derived from the California soils $\left(K_{1}=0.29, K_{2}=0.23\right)$, were similar to microscopic biomass $\mathrm{C}$ estimates at the various depths showing that the relationship developed for California forest is applicable to soils of different origin vegetation and depth (Fig. 3a).

\section{Alternative models}

Figure 2 represents the relationships between microscopic and CFI biomass $\mathrm{C}$ for the California forest soils calculated according to Eq. 4 (Fig. 2a) and by two other possible models. Figure $2 b$ shows the effect of directly estimating a proportion of the control to subtract without reference to the $F_{\mathrm{C}} / U F_{\mathrm{C}}$ ratio:

$$
M B C=\left(F_{C}-P U F_{C}\right) / 0.41
$$

Figure $2 c$ represents the effect of removing $K_{2}$ from the model so that Eq. 3 becomes:

$$
M B C=\left[F_{C}-\left(U F_{C} K_{1}\left(\frac{F_{C}}{U F_{C}}\right)\right)\right] / 0.41
$$

which simplifies to

$$
M B C=\left(F_{C}-F_{C} K_{1}\right) / 0.41
$$

The best prediction of microscopic biomass $C$ in the California soils with this model occurred when $K_{1}$ was 0.47 , thus Eq. 8 becomes:

$$
M B C=F_{C} 0.78
$$

This simplified relationship is appealing with a $R^{2}$ of 0.87 but makes no reference to the control $\left(U F_{\mathrm{C}}\right)$ and is therefore less flexible. The $F_{C} / U F_{C}$ ratio is an indicator of soil substrate availability and is also useful in interpreting the variability encountered in MBC measurements in soils with different origins, organic matter contents, and depths. In addition, the background soil respiration $\left(U F_{\mathrm{C}}\right)$ is useful to compare changes in soil biomass activity across soil type and depth and studies that determine the fate of tracer $C$. The effect of using the above three models (Fig. 2) for a combination of the KBS poplar plantation soils $(0-100 \mathrm{~cm})$ 

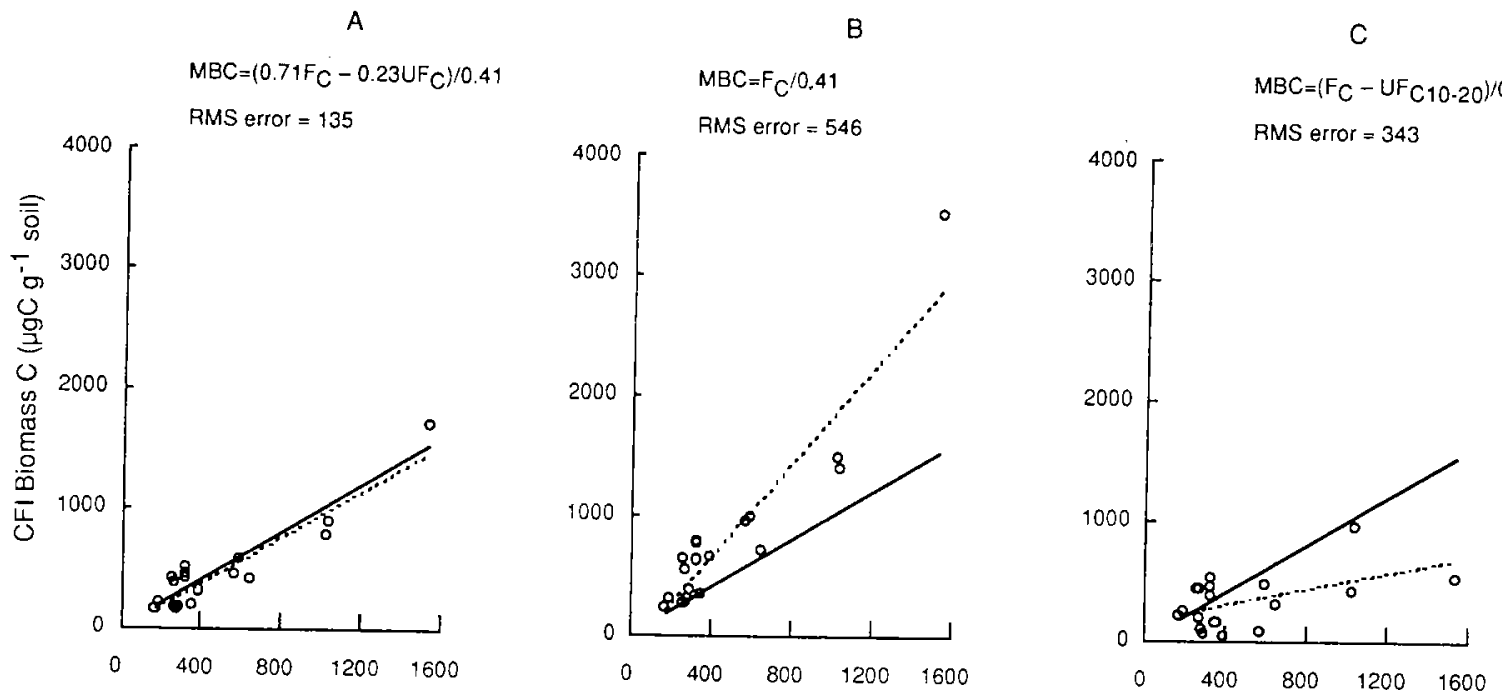

Fig. 1. The linear regression analysis of microscopic biomass $\mathrm{C}$ versus $\mathrm{CFI}$ biomass $\mathrm{C}$ for the California forest soils using $(\mathrm{A}) \mathrm{MBC}=\left(F_{C}(1\right.$ $\left.\left.-K_{1}\right)-U F_{C} K_{2}\right) / 0.41, U F_{C}=0-10 \mathrm{~d}, K_{1}=0.29$, and $K_{2}=0.23 ;(\mathrm{B}) \mathrm{MBC}=F_{\mathrm{C}} / 0.41$; and $(\mathrm{C}) \mathrm{MBC}=\left[F_{\mathrm{C}}-U F_{\mathrm{cl} 0-20}\right] / 0.45$. The broken lines represent the fitted regressions and the solid lines a 1:1 relationship between microscopic and CFI biomass C. Root mean square (RMS) errors are the square root of the average of the squared difference between predicted and measured CFI biomass $C$ for the three models shown. RMS $=\sqrt{\frac{\sum(\mathrm{CFI}-\mathrm{MIC})^{2}}{\mathrm{~N}}}$
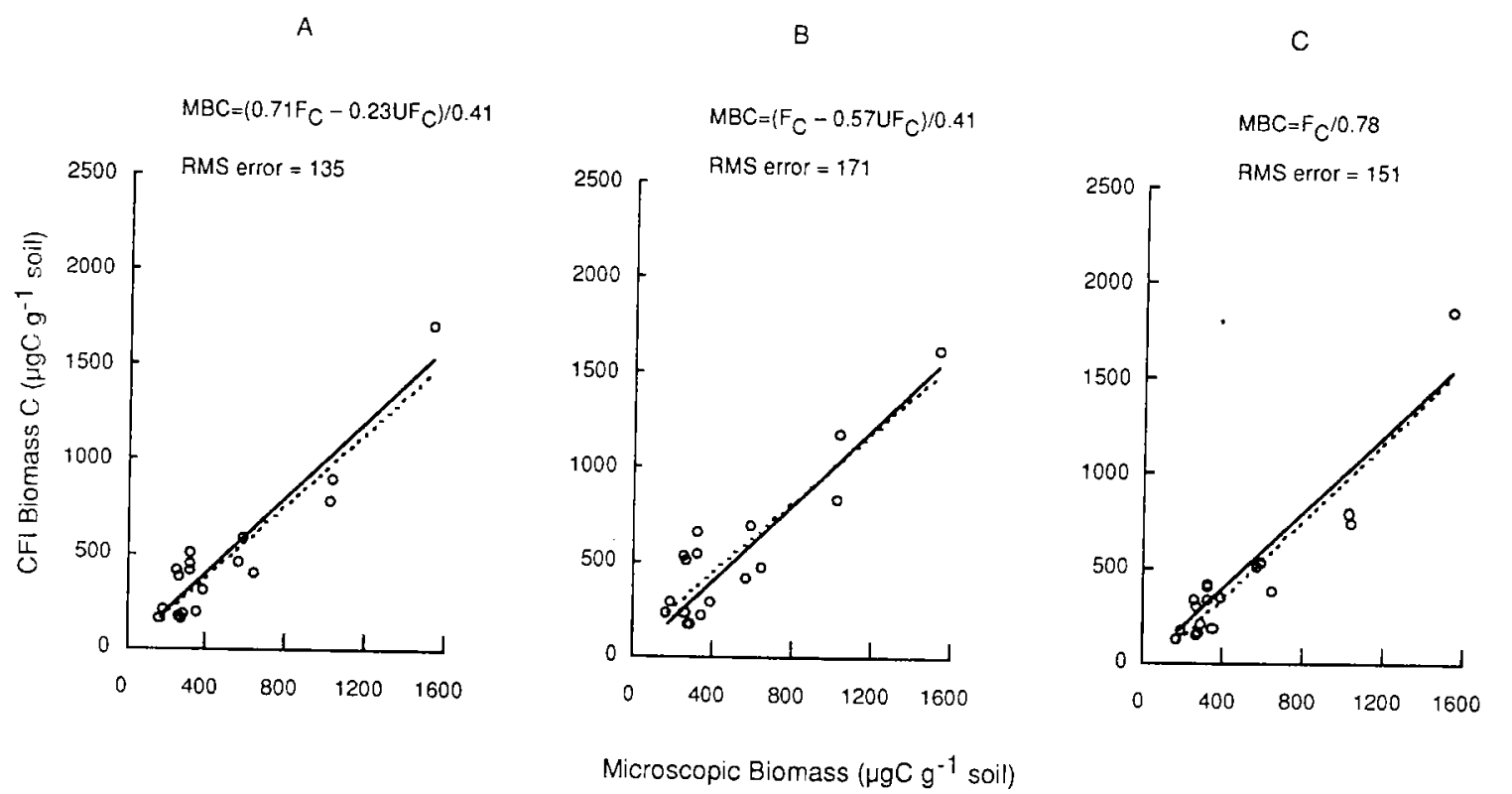

Fig. 2. Alternative models of the partial control relationship for the California forest soils. (A) $\mathrm{MBC}=\left(F_{\mathrm{C}}\left(1-K_{\mathrm{l}}\right)-U F_{\mathrm{C}} \mathrm{K}_{2}\right) / 0.41,(\mathrm{~B}) \mathrm{MBC}$ $=\left(F C-P U F_{\mathrm{C}}\right) / 0.41,(\mathrm{C}) \mathrm{MBC}=F_{\mathrm{C}} K_{1} / 0.41$. The broken lines represent the fitted regressions and the solid lines a $1: 1$ relationship between microscopic and CFI biomass C. Root mean square (RMS) errors are the square root of the average of the squared difference between predicted and measured CFI biomass $\mathrm{C}$ for the three models shown. RMS =

$$
\sqrt{\frac{\Sigma(\mathrm{CFI}-\mathrm{MIC})^{2}}{\mathrm{~N}}}
$$

and the data from the agroecosystem plots is shown in Fig. 3 . In this figure the line shown in all graphs is a 1:1 relationship between microscopic biomass $\mathrm{C}$ and $\mathrm{CFI}$ biomass $\mathrm{C}$ calculated according to the three models. The root mean square error (RMS) is a measure of the deviation of the calculated CFI values from those predicted by microscopy.
The primary model (Eq. $4, K_{1}=0.29$ and $K_{2}=0.23$, Fig. 3a) resulted in a RMS error of 62 for the samples from the agronomic plots and a RMS error of 22 for the soils of the poplar plantation. Direct estimation of $P$ (Eq. 6, $P=0.57$ ) increased the prediction error for both agronomic and poplar plantation soils. The simplified model (Eq. 8, $K_{1}=0.47$, Fig. 3c) 

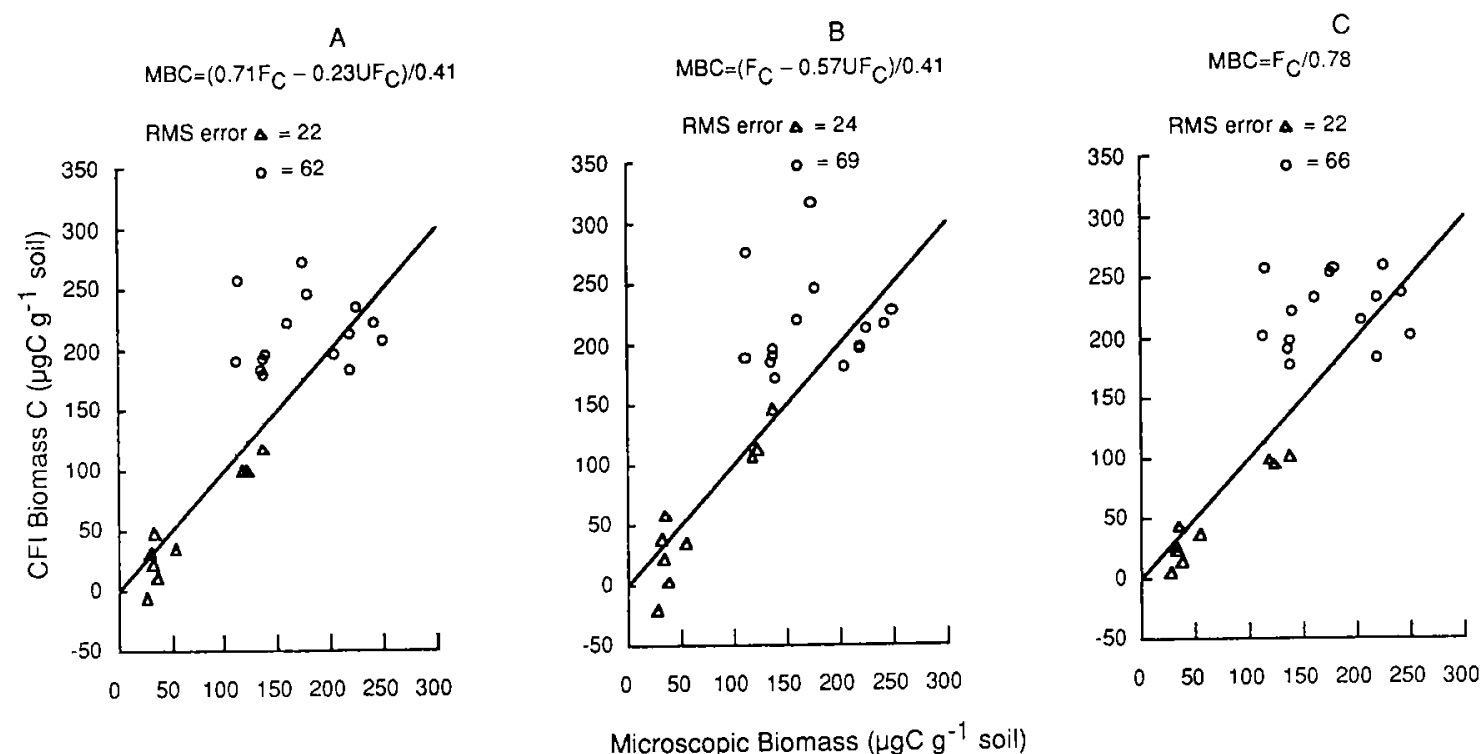

Fig. 3. Alternative models of the partial control relationship, $\mathrm{MBC}=\left(F_{\mathrm{C}}\left(1-K_{1}\right)-U F_{\mathrm{C}} K_{2}\right) / 0.41$ for the for the Michigan Poplar and agronomic soils $(\Delta=$ poplar, $0=$ agronomic). The line represents a 1:1 relationship. Root mean square (RMS) errors are the square root of the average of the squared difference between predicted and measured CFI biomass $C$ for the three models shown. RMS = $\sqrt{\frac{\sum(\mathrm{CFI}-\mathrm{MIC})^{2}}{\mathrm{~N}}}$

resulted in a similar error for the poplar plantation samples, but increased the error of the surface agronomic soils to 66 . These results suggest that Eq. 4 with the parameters $K_{1}=$ 0.29 and $K_{2}=0.23$ is most useful in calculating CFI biomass $\mathrm{C}$ across soil depth and cultural treatment.

Recalculation of published biomass data, where the fumigation flush and the $0-$ to $10-\mathrm{d}$ and $10-$ to 20 -d control respiration have been given, provided another test of the partial control equation (Table 4). This does not result in validation since no corresponding microscopic biomass measurements are available, but it does show the effect of applying the corrected control concept. The comparison of methods of calculation covered a wide range of soil types and treatments and ranged from small site effects such as burning tall grass prairie in Kansas to large effects, such as where wood chips were added to bentonite spoil in Wyoming. The desert to mountain summit transect in California allowed for the effects of soil plant interactions along a gradient. The use of $\mathrm{MBC}=F_{\mathrm{C}} / 0.41$ resulted in values much higher than obtained by the other methods of calculation. Full subtraction of the 0 - to 10 -d or 10- to 20-d controls gave low results for the mine spoil plus wood chips and a negative biomass in the desert to mountain transect. The $\mathrm{MBC}=F_{\mathrm{C}} / 0.78$ equation is closely related to $\mathrm{MBC}=F_{\mathrm{C}} / 0.41$ both appear to give high results when $U F_{\mathrm{C}}$ approaches $F_{\mathrm{C}}$.

\section{DISCUSSION}

Microscopic examination of the soil matrix remains the most direct method to estimate soil microbial biomass. It was used to calibrate the CFI method by Jenkinson (1976), but not by Voroney and Paul (1984), who utilized ${ }^{14} \mathrm{C}$ cells labeled in situ. Chloroform-fumigation studies on soil with relatively inactive soil microbial populations have shown good correlation to microscopic biomass (Jenkinson et al. 1976; Paul and Voroney 1984; Martikainen and Palojärvi 1990). However, studies on organic-matter-amended soils and forest soils with high fungal biomass have shown poor correlation between microscopic biomass and an uncorrected CFI (Schnürer et al. 1985; Ingham et al. 1991). These have been attributed to the lack of differentiation between live and dead biomass, extraction efficiencies, and abiotic variables, such as moisture (Schnürer et al. 1985; Nilsson and Rülcker 1992). In addition, the variation in total fungal hyphal lengths and bacterial numbers and diameters is influenced by soil physiochemical characteristics and the nature of the plant community. Schnürer et al. (1985) found that hyphal diameters declined in subsurface soil as a function of decreasing soil SOM levels. The degree of hyphal vacuolization can also influence fungal biomass estimates by microscopy (Paul and Clark 1996). For these reasons, the lack of correlation between microscopy and CFI could be attributable to problems associated with errors in microscopy (Stahl et al. 1995) and in converting biovolumes to biomass (Bottomley 1994).

The low rate of ${ }^{14} \mathrm{C}$-maize decomposition in the non-inoculated fumigated soils compared with the unfumigated soil indicates that the mineralization of non-microbial soil $\mathrm{C}$ does not occur at the same rate as in the control. This questions the validity of subtracting the entire control respiration, $0-10 \mathrm{~d}$ in preincubated soil (Cerri and Jenkinson 1981) and $10-20 \mathrm{~d}$ in disturbed soil (Jenkinson 1976), from the fumigated soil to estimate MBC. However, the subtraction of some proportion of the control is indicated because some ${ }^{14} \mathrm{C}$ maize decomposition did occur after fumigation. Smith et al. (1995) also found fumigation to reduce the rate of min- 


\begin{tabular}{|c|c|c|c|c|c|c|c|c|c|}
\hline \multirow[b]{2}{*}{ Location/soil } & \multicolumn{3}{|c|}{$\mathrm{CO}_{2}-\mathrm{C}\left(\mu \mathrm{g} \mathrm{g}^{-\mathrm{I}}\right)$} & \multicolumn{6}{|c|}{ Biomass $\mathrm{C}\left(\mu \mathrm{g} \mathrm{g}^{-1}\right)$} \\
\hline & $F_{C}$ & $U F_{C}$ & $U F_{C 10-20}$ & $\begin{array}{c}F_{C}-U F_{C} \\
10.41 \\
\end{array}$ & $F_{C} 0.41$ & $\begin{array}{c}\left(F_{C}-U F_{C 10-20}\right) \\
10.45 \\
\end{array}$ & $\begin{array}{l}1.73 F_{C^{-}} \\
0.56 U F_{C} \\
\end{array}$ & $\begin{array}{c}\left(F_{C}-0.57 U F_{C}\right) \\
/ 0.41 \\
\end{array}$ & $F_{C} / 0.78$ \\
\hline \multicolumn{10}{|l|}{ Wyoming ${ }^{\mathbf{z}}$} \\
\hline Bentonite spoil & 89 & 25 & 10 & 156 & 217 & 176 & 140 & 182 & 114 \\
\hline Spoil/woodchips & 583 & 562 & 491 & 51 & 1422 & 204 & 694 & 641 & 747 \\
\hline \multicolumn{10}{|l|}{ Kansas ${ }^{y}$} \\
\hline Tall grass prairie & 818 & 331 & 229 & 1188 & 1995 & 1308 & 1230 & 1535 & 1049 \\
\hline Tall grass prairie (burn) & 901 & 367 & 320 & 1302 & 2198 & 1291 & 1353 & 1687 & 1155 \\
\hline \multicolumn{10}{|l|}{ Nebraska $^{x}$} \\
\hline Native sod & 620 & 276 & 212 & 339 & 984 & 906 & 918 & 1128 & 795 \\
\hline No till & 335 & 174 & 119 & 393 & 508 & 480 & 482 & 575 & 429 \\
\hline Bare fallow & 225 & 79 & 56 & 356 & 378 & 375 & 345 & 439 & 288 \\
\hline \multicolumn{10}{|l|}{ Saskatchewan" } \\
\hline Wheat/fallow & 246 & 48 & 24 & 483 & 600 & 494 & 399 & 533 & 315 \\
\hline \multicolumn{10}{|l|}{ Rothamsted $^{\mathbf{v}}$} \\
\hline Wooded & 780 & 424 & 367 & 868 & 1902 & 917 & 1112 & 1313 & 1000 \\
\hline Fallow & 129 & 86 & 73 & 105 & 315 & 125 & 175 & 195 & 165 \\
\hline \multicolumn{10}{|l|}{ California" } \\
\hline Ocotolio: between plants & 11 & 17 & 14 & $(-15)$ & 26 & $(-6)$ & 10 & 3 & 14 \\
\hline under plants & 125 & 109 & 74 & 39 & 304 & 114 & 155 & 153 & 160 \\
\hline Mtn Spring: between plants & 91 & 45 & 40 & 112 & 220 & 113 & 132 & 159 & 117 \\
\hline under plants & 340 & 243 & 217 & 237 & 826 & 274 & 452 & 491 & 436 \\
\hline Jacumbu: between plants & 171 & 89 & 68 & 200 & 417 & 230 & 246 & 293 & 219 \\
\hline under plants & 519 & 476 & 327 & 105 & 1267 & 426 & 631 & 604 & 665 \\
\hline Laguna Summit: between plants & 420 & 219 & 213 & 490 & 1037 & 460 & 604 & 720 & 538 \\
\hline under plants & 686 & 589 & 438 & 237 & 1672 & 551 & 857 & 854 & 879 \\
\hline
\end{tabular}

${ }^{2}$ Woods and Schuman (1988).

YOjima (1987).

${ }^{x}$ Follett and Schimel (1989).

woroney and Paul (1984).

venkinson and Powlson (1976).

"Collins and Cavigelli 1996.

eralization of added maize straw to $20 \%$ that of the unfumigated control and suggested that $20 \%$ of $\mathrm{UF}_{\mathrm{C}}$ should be subtracted. However, in the soils studied here it was necessary to subtract a greater proportion of the control $(57 \%)$ than indicated by the ${ }^{14} \mathrm{C}$ decomposition study if a constant proportion of $U F_{C}$ was subtracted from $F_{C}$.

Re-inoculation of fumigated soil contributes to problems with the interpretation of the control in that increased amounts of non-microbial $\mathrm{C}\left({ }^{14} \mathrm{C}\right.$-maize $)$ are mineralized. The surviving organisms in the non-inoculated fumigated samples are of low diversity and dominated by bacteria (Shields et al. 1974; Lynch and Panting 1980; Ingham and Horton 1987). Protozoa and fungi appear late in the 10-d post-fumigation incubation period (Brooks and Paul 1987; Ingham and Horton 1987). In the absence of inoculation, the microbial population in the fumigated soil is less diverse and has a limited potential to degrade complex substrates such as SOM and cellulose. Inoculation with lysobacter, a highly lytic organism, has been suggested (McGill et al. 1986), but has not been routinely used. In our study, the limited microbial community in the non-inoculated fumigated mineralized the ${ }^{14} \mathrm{C}$-maize straw to a lesser extent than in the unfumigated or the fumigated reinoculated samples. The limited potential to degrade non-microbial $\mathrm{C}$ in non-inoculated fumigated soils helps to standardize the partial control relationship as determined by the $F_{\mathrm{c}} / U F_{\mathrm{c}}$ ratio

The use of the CFI partial control relationship has the advantage of assaying fields soils directly with no preincubation or extended incubations beyond $10 \mathrm{~d}$. This makes this technique suitable for tracer studies where preincubation of soils is undesirable and mineralized $\mathrm{CO}_{2}$ can be collected immediately from samples collected in the field. The determination of $U F_{\mathrm{c}}$ also gives very useful information on relative soil $\mathrm{C}$ mineralization potentials. It also is useful in maintenance energy and microbial growth rate calculations (Harris and Paul 1994).

There are a large number of CFI studies that have not been standardized against direct microscopy, against each other or were conducted on subsurface soil. The intent of this study was to validate the CFI method for tracer work and develop a realistic partial control relationship. The comparison of microbial biomass methodologies showed good agreement in revealing temporal trends and changes associated with soil depth. This indicated that the different constants and variables used were applicable across soils and soil depth.

\section{ACKNOWLEDGMENTS}

This research was supported by the National Science Foundation, (grants BSR 8907565 and BSR 8702332) with 
support from the Michigan Agricultural Experiment Station. The NSF, REU program provided critical additional support and we gratefully acknowledge this program and the students it supported. We thank Nancy Ritchie for her contributions to this research.

Anderson, J. P. E. and Domsch, K. H. 1978. Mineralization of bacteria and fungi in chloroform fumigated soils. Soil Biol. Biochem. 10: 207-213.

Babiuk, L. A. and Paul, E. A. 1970. The use of fluorescein isothiocyanate in the determination of microbial biomass of grassland soil. Can J. Microbiol. 16: 57-62.

Badalucco, L. P., Nannipieri, P. and Grego, S. 1990. Microbial biomass and anthrone-reactive carbon in soils with different organic matter contents. Soil Biol. Biochem. 22: 899-904.

Bakken, L. R. and Olsen, R. A. 1983. Buoyant densities and dry matter contents of microorganisms: conversion of a measured biovolume into biomass. Appl. Environ. Microbiol. 45: 1188-1195

Bloem, J. Veninga, M. and Sheperd, J. 1995. Fully automated determination of soil bacterial numbers, cell volumes and frequencies of dividing cells by confocal laser scanning microscopy and image analysis. Appl. Environ. Microbiol. 61: 926-936.

Bottomley, P. S. 1994. Light microscopic methods for studying soil microorganisms. Pages 81-105 in R. W. Weaver, J. S. Angle, and P. S. Bottomley, eds. Methods of soil analysis. Part 2. Microbiological and biochemical properties. Soil Science Society of America, Inc., Madison, WI.

Brooks, P. D. and Paul, E. A. 1987. A new automated technique for measuring respiration in soil samples. Plant Soil 101: 183-187. Cerri, C. C. and Jenkinson. D. S. 1981. Formation of microbial biomass during the decomposition of ${ }^{14} \mathrm{C}$ labeled ryegrass in soil. J. Soil Sci. 32: $619-626$.

Collins, H. P. and Cavigelli, M. 1995. Soil microbial community structure along a transect in the Laguna mountains of Southern California (In Press).

Couteaux, M., Henkinet, R. and Bottner, P. 1990. Anomalies in microbial biomass measurements in acid organic soils using extractable carbon following chloroform fumigation. Soil Biol. Biochem. 22: 955-957.

Faegri, A., Torsvik, V. L. and Goksoyr, J. 1977. Bacterial and fungal activities in soil: separation of bacteria and fungi by a rapid fractionated centrifugation technique. Soil Biol. Biochem. 9: 105-112.

Follett, R. F. and Schimel, D. S. 1989. Effects of tillage practices on microbial biomass dynamics. Soil Sci Soc. Am. J. 53: 1091-1096.

Hanssen, J. F., Thingstad, T. F. and Goksoyr, J. 1974. Evaluation of hyphal lengths and fungal biomass in soil by membrane filter technique. Oikos 25: 102-107.

Harris, D. and Paul, E. A. 1994. Measurement of bacterial growth rates in soil. Appl. Soil Ecol. 1: 227-290.

Horwath, W. R. and Paul, E. A. 1994. Microbial Biomass. Pages 753-2773 in R. W. Weaver, J. S. Angle, and P. S. Bottomley, eds. Methods of soil analysis. Part 2. Microbiological and Biochemical Properties. Soil Science Society of America, Inc., Madison, WI.

Horwath, W. R., Pregitzer, K. S. and Paul, E. A. 1994. ${ }^{14} \mathrm{C}$ allocation in tree-soil systems. Tree Physiol. 14: 1163-1176.

Ingham, E. R., Griffiths, R. P., Cromack, K. and Entry, J. A. 1991. Comparison of direct verses fumigation incubation microbial biomass estimates from ectomycorrhizal mat and non-mat soils. Soil Biol. Biochem. 23: 465-471.

Ingham, E. R. and Horton, K. A. 1987. Bacterial, fungal and protozoan responses to chloroform fumigation in stored soil. Soil Biol. Biochem. 19: 545-550.

Ingham, E. R. and Klein, D. A. 1984. Soil fungi: measurement of hyphal length. Soil Biol. Biochem. 16: 279-280.

Jenkinson, D. S. 1976. The effect of biocidal treatments on the metabolism in soil. IV. The decomposition of fumigated organisms in soil. Soil Biol. Biochem 8: 203-208.

Jenkinson, D. S. and Powlson, D. S. 1976. Effects of biocidal treatments on metabolism in soil. V. A method for measuring the soil biomass. Soil Biol. Biochem. 8: 209-213.

Jenkinson, D. S., Powlson, D. S. and Wedderburn, R. W. M. 1976. The effects of biocidal treatment son metabolism in soil. III. The relationship between soil biovolume, measured by optical microscopy, and flush of decomposition caused by fumigation Soil Biol. Biochem 8: 189-202.

Lynch, J. M. and Panting, L. M. 1980. Cultivation and the soil biomass. Soil Biol. Biochem 12: 29-33.

Martens, R. 1985. Limitations in the application of the fumigation technique for biomass estimations in amended soils. Soil Biol. Biochem 17: 57-63.

Martikainen, P. J. and Palojärvi, A. 1990. Evaluation of the fumigation-extraction method for the determination of microbial C and $\mathrm{N}$ in a range of forest soils. Soil Biol. Biochem 22: 797-802.

McGill, W. B., Cannon, K. R., Robertson, J. A. and Cook, F. D. 1986. Dynamics of soil microbial biomass and water-soluble organic $\mathrm{C}$ in Breton after 50 years of cropping two rotations. Can. J. Soil Sci. 66: 1-19.

Nilsson, M. and Rülker, C. 1992. Seasonal variation of active fungal mycelium in an oligotrophic Sphagnum mire, Northern Sweden. Soil Biol. Biochem 24: 795-804.

Norton, J. M., Smith, J. and Firestone, M. K. 1990. Carbon flow in the rhizosphere of ponderosa pine seedlings. Soil Biol. Biochem 22: $449-455$.

Ojima, D. S. 1987. The short and long term effects of burning on tallgrass prairie ecosystem properties and dynamics. Ph.D Dissertation, Colorado State University, Ft. Collins, CO.

Paul, E. A. and Clark, F. E. 1996. Soil microbiology and biochemistry. 2nd edn. Academic Press, Inc., San Diego, CA.

Paul, E. A. and Voroney, R. P. 1984. Field interpretation of microbial biomass activity measurements. Pages $509-514$ in M. J. Klug and C.A. Reddy. eds. Current perspectives in microbial ecology. American Society of Microbiology, Washington, DC.

Ramsay, A. J. 1984. Extraction of bacteria from soil: efficiency of shaking or untrasonication as indicated by direct counts and autoradiography. Soil Biol. Biochem. 16: 475-481.

Robertson, G. P., Collins, H. P., Gage, S. H., Gross, K. L., Halstead, S. J., Harwood, R. H., Klingensmith, K. M., Klug, M. J. and Paul E. A. 1996 Long term research in agricultural ecology: Objectives and establishment of a site in the US Midwest. Agric. Ecosys. Environ. (in Press).

Schnürer, J., Clarholm, M. and Rosswall, T. 1985. Microbial biomass and activity in an agricultural soil with different organic matter contents. Soil Biol. Biochem. 17: 611-618.

Shields, J. A., Paul, E. A. and Lowe, W. E. 1974. Factors influencing the stability of labeled microbial materials in soils. Soil Biol. Biochem 6: 31-37.

Smith, J. L., Halvorson, J. J. and Bolton, H., Jr. 1995. Determination and use of a corrected control factor in the chloroform fumigation method of estimating microbial biomass. Biol. Fertil. Soils 19: 287-291.

Smith, J. L. and Paul, E. A. 1990. The significance of soil microbial biomass estimations. In J. M. Bollag and G. Stotzky. eds. Soil biochemistry. Vol. 6. Marcel Dekker, Inc., New York, NY.

Stahl, P. D., Parkin, T. B. and Each, N. S. 1995. Sources of error in direct microscopic methods for estimation of fungal biomass in soil. Soil Biol. Biochem. 27: 1091-1098.

Voroney, R. P. and Paul, E. A. 1984. Determination of $k_{c}$ and $k_{N}$ in situ for calibration of the chloroform fumigation incubation method. Soil Biol. Biochem. 16: 9-14.

Woods, L. E. and Schuman, G. E. 1988. Cultivation and slope position effects on soil organic matter. Soil Soc. Am. J. 52: 1371-1376. 